\title{
The income structure of smallholder forest farmers in rural Sumbawa, Indonesia
}

\author{
BUDIMAN ACHMAD", DIAN DINIYATI ${ }^{\text {}}$ \\ Institute for Research and Development on Agroforestry Technology. Jl. Raya Ciamis-Banjar Km 4, Ciamis 46201, West Jawa, Indonesia. Tel.: +62-265- \\ 771352, Fax.: +62-265-775866, "email: budah59@yahoo.com ${ }^{* v}$ dian_diniyati@yahoo.com
}

Manuscript received: 26 September 2017. Revision accepted: 30 April 2018.

\begin{abstract}
Achmad B, Diniyati D. 2018. The income structure of smallholder forest farmers in rural Sumbawa, Indonesia. Biodiversitas 19: 936-946. This research investigated the economic well-being of forest farmers in Labuhan Badas Village, Sumbawa regency of Indonesia. It aimed: (i) to describe the daily economic activities of community-based forest (HKm) farmers who reside inside the state forest and of farmers in privately owned forest (POF) who reside outside the state forest areas; and (ii) to analyse their income structure in relation to the corresponding economic activities. The research was conducted from August 2015 to April 2016. The survey sample consisted of $34 \mathrm{HKm}$ and $34 \mathrm{POF}$ farmers who were selected purposively. Data collected through interview and focus group discussion techniques were analyzed descriptively. The research determined that the incomes of HKm farmers were generated from 14 sources, mainly from activities in the non-agricultural sector, while those for POF farmers were generated from 12 sources mainly from activities in the agricultural sector. The total income of HKm farmers was significantly lower than the income of POF farmers and indicated a moderate level of economic disadvantage. The economic welfare of farmers in both research locations has been assessed to be below an adequate level. Therefore various economic innovations such as the cultivation of honey bees and the processing of unused potential resources (e.g. making wine from cashew fruit) are needed to accelerate the attainment of a decent level of economic well-being
\end{abstract}

Keywords: Daily economic activities, households, income sources, inside state forest, outside state forest

\section{INTRODUCTION}

Forests are frequently described as a resource that can be drawn upon to alleviate poverty in millions of rural households in developing countries (Rasmussen et al. 2017). This is because forests provide various products that can support the livelihoods of rural communities. Some products can be sold for cash (commercial goods), others can be directly consumed (subsistence goods), and yet others sustain crucial aspects of the environment (ecological goods). The forest contribution to these three aspects plays an essential role in the well being of nearby rural communities, who therefore are rendered dependent on the forest (Newton et al. 2016). There is a strong relationship between the social, economic and ecological dimensions of the comunities' dependence on the forest (Olsson and Galaz 2012) and in order to obtain sustainable incomes from the forest, communities play close attention to the forest's ecological requirements.

The income level of farmer households in Labuhan Badas Village of rural Sumbawa, Indonesia, has been judged to be relatively low despite the richness of the natural resources in the vicinity of the village. Labuhan Gadas village administratively includes two different forest management systems, namely community-based forest management (CBFM) located in the state production forest area, and private forest management located in the privately owned forest area. The CBFM system is managed by community-based forest ( $\mathrm{HKm}$ ) farmers, while the latter system is managed by private forest farmers. The income sources of the $\mathrm{HKm}$ farmers is different from the income sources of the private forest farmers (POF). This is because the regulation for CBFM is more rigid than for the private forest management. In the $\mathrm{HKm}$ area, under specific regulation (CBFM rule) which controls certain factors such as tree composition, pattern of plantation, time of harvesting and forest yield sharing, the community-based forest $(\mathrm{HKm})$ farmers have limited say in the development of the land. Moreover, there are differences between their living environment and their daily economic activity pattern.

In some previous studies of this kind, the income of farmers has been considered in relation to various subsidised inputs (capital, fertilizer, seedlings etc) and incentives (extension and training) without much consideration of the farmers' living environment (Kalavathi et al. 2010; Zhao 2014; Pandey and Dwivedi 2016). In Labuhan Badas Village in rural Sumbawa the income level of farmers is relatively low despite the richness of their natural resources. Among the reasons for this could be problems in allocating time efficiently to daily economic activity. More effective allocation of subsidies and incentives to optimise work practices could contribute to raising farmers' welfare. By identifying current activity schedules of farmers, socio-economic analysis of the forest communities could assist in diagnosing farmers' capacity for undertaking additional income-generating activities such as the cultivation of honey bees.

Unlike the farmers with privately owned forest (POF), the $\mathrm{HKm}$ farmers operating under the CBFM regulations have not been permitted to cut down trees other than cash crops and fruit trees. The differences in the system of land 
tenure and use between the two groups and how this connects to differences in forest management are important matters for analysis. Also, identification of the income of farmers based on their status (either as $\mathrm{HKm}$ or as POF farmers) and of the relationship between incomes and their pattern of daily economic activity pattern would contribute information of value in helping accelerate poverty alleviation in the communities.

Thus, the research described in this paper undertook the task of investigating in Labuhan Badas Village of rural Sumbawa: (i) the structure of farmer incomes; (ii) a comparison of the total household incomes between farmers with community-based forest and farmers with privately managed forest; and (iii) the daily economic activity patterns of the farm households in the two groups. This undertaking was an attempt to identify ways of optimizing work schedules to allow for new income-earning enterprises for farmer households. The results from this research was expected to be utilized by government to develop programmes and strategies to increase farmers' welfare without impacting adversely on the quality of the environment.

\section{MATERIALS AND METHODS}

\section{Study area}

The research was carried out in Labuhan Badas Village, Sumbawa District, West Nusa Tenggara, Indonesia from
August 2015 and April 2016. The village region comprises areas both inside and outside the state production forest; namely, community-based forest areas ( $\mathrm{HKm}$ ) inside and private forest areas (POF) outside, as shown in Figure 1.

\section{Data-collecting techniques}

Primary data were gathered through an interview technique using structured questionnaires and through focus group discussions (FGD). A total of 68 farmer respondents - 34 community-base forest $(\mathrm{HKm})$ farmers and 34 farmers in privately owned forest (POF) - were selected purposively (Sugiyono 2013). The primary data collected by interview were characteristics of farmer households, farm incomes and daily economic activities. Secondary data was obtained from relevant written reports and references.

\section{Data analysis}

Data about farmer incomes were grouped into two categories i.e income from on-farm and from off-farm endeavours. Analysis of the data, classed the sources of the income according to the various endeavour undertaken by the farm households

Data from interviews about household characteristics, daily economic activities and structure of household incomes were analysed as follows:

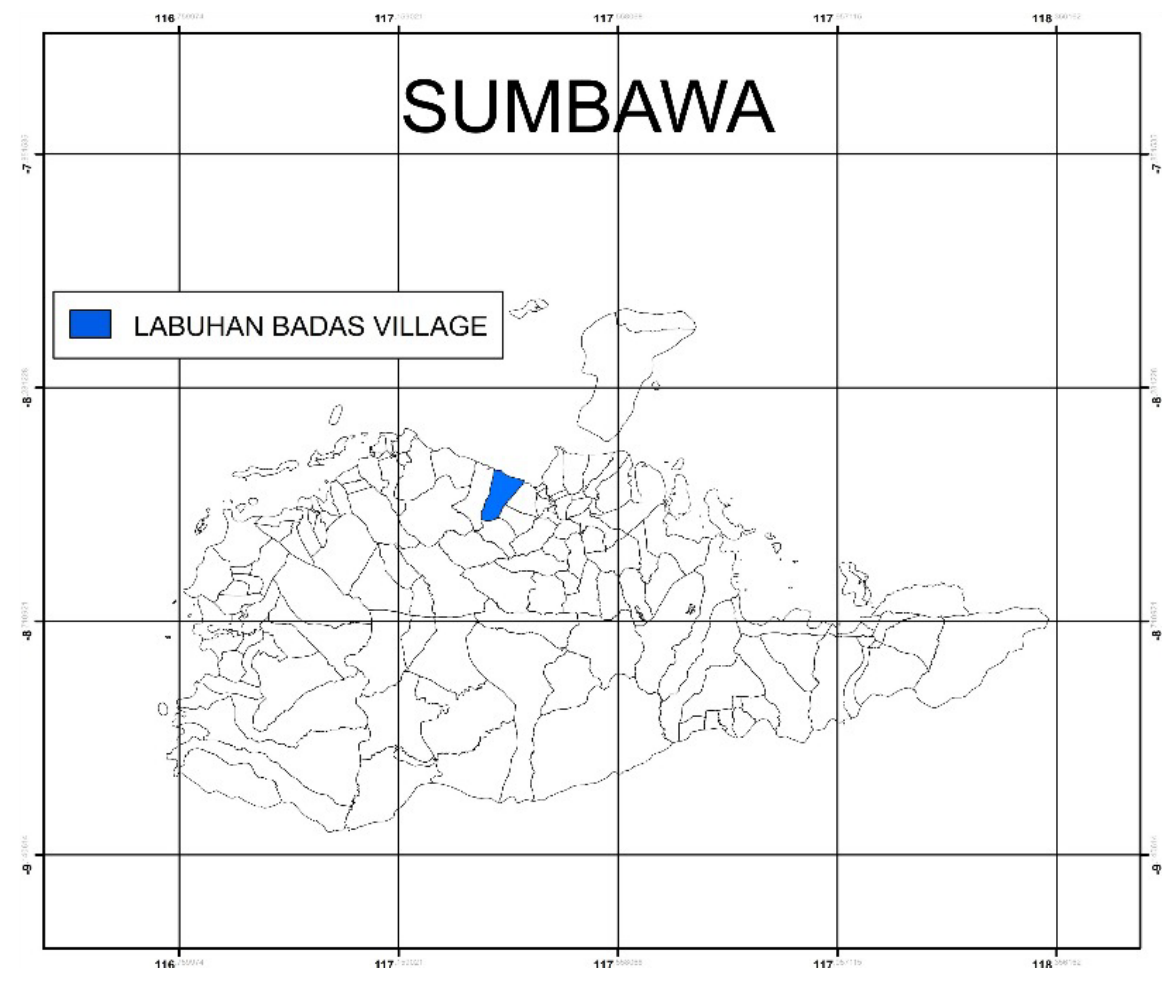

\section{RESEARCH LOCATION ( LABUHAN BADAS VILLAGE) PREPARED BY INSTITUTE FOR RESEARCH AND DEVELOPMENT ON AGROFORESTRY TECHNOLOGY}

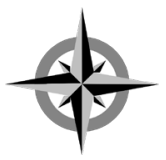

1:1.000.000

$\begin{array}{llll}00,0,2 & 0,4 & 0,6 & 0,8\end{array}$ Miles

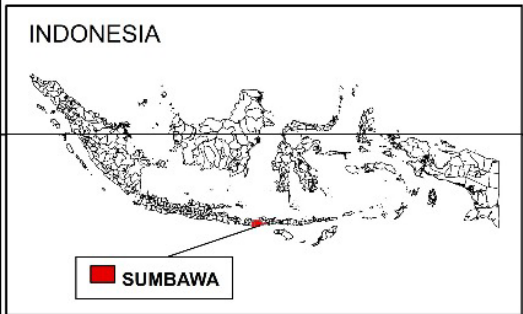

Figure 1. The location of Labuhan Badas Village, Sumbawa District, West Nusa Tenggara, Indonesia $\left(08^{0} 47.244^{\prime} \mathrm{S}, 117^{0} 32.959^{\prime} \mathrm{E}\right)$ which administratively includes both state production forest and privately owned forest 


\section{Characteristics of farm households}

For ease of interpretation, the household data were assembled and then tabulated according to demographic characteristics such as the ages of household members, their years of education, and their types of jobs. This data was analysed to illustrate similarities and differences in demographic and socioeconomic characteristic between the community-based forest farmers and the private forest farmers.

\section{Daily economic activities of farm households}

Data and information about daily economic activities of farmers, as obtained using focus group discussions (FGD), were assembled and analyzed descriptively. The FGD method was employed with both farmer groups i.e. the community-based forest $(\mathrm{HKm})$ farmers and the private forest farmers (POF), to explore the daily economic activities that were closely related to household daily incomes. The Focus Group Discussions were performed twice with each farmer group: the first FGD in each group involved 10 female farmer respondents, key persons from local governments and forest entrepreneurs. The second FGD in each group was performed in similar manner but involved only male farmers. The respondents involved in the discussion represented not only both genders but a range of ages. The information collected through this FGD approach was used to provide context, but was not necessarily used in tests of hypotheses.

\section{Structure of incomes for farmer households}

The incomes from each household economic endeavor were estimated from simple statistical calculation, by subtracting from the gross income all the expenditure outlayed in the endeavor. The incomes were calculated on an annual basis. The percentages of the total household income derived from on-farm endeavors and from off-farm endeavors were calculated as follows:

$$
\begin{aligned}
& P_{\mathrm{t}}=P_{\text {on }}+P_{\text {of }} \\
& K_{\text {on }}=\frac{P_{\text {on }}}{P_{\mathrm{t}}} \times 100 \% \\
& K_{\text {of }}=\frac{P_{\text {of }}}{P_{\mathrm{t}}} \times 100 \%
\end{aligned}
$$

Where:

$P t:$ Incomes of farm households (IDR/year);

$P_{o n}$ : Incomes earned from on-farm endeavor (IDR/year);

$P_{o f}$ : Incomes earned from off-farm endeavor (IDR/year);

$K_{o n}$ : contribution of incomes from on-farm endeavors (\%);

$K_{o f}$. contribution of incomes from off-farm endeavors (\%)

Comparison of total incomes between the community-based forest farmers ( $\mathrm{HKm})$ and farmers with privately owned forest (POF)

The mean values for total household income earned by the HKm farmer group and by the POF farmer group were compared statistically by t-test with the aid of SPSS 13.0 software.
The hypotheses tested were as follows: (i) $\mathrm{H}_{\mathrm{o}}$ : total income of $\mathrm{HKm}$ farmers = total incomes of POF farmers; (ii) $\mathrm{H}_{\mathrm{a}}$ : total income of $\mathrm{HKm}$ farmers $\neq$ total incomes of POF farmers. Where, $\mathrm{H}_{\mathrm{o}}=$ null hypothesis; and $\mathrm{H}_{\mathrm{a}}=$ alternative hypothesis.

\section{Incomes distribution}

The distribution of levels of annual income across farm households is an important measure of the general economic welfare of the forest farming communities of Labuhan Badas Village. An estimation of this income distribution was determined by employing the Gini index (G-index) approach, as formulated below in equation (4).

$$
G=\sum_{k=1}^{n}\left(X_{i+1}-X_{i}\right)\left(Y_{i}+Y_{i+1}\right)
$$

Where

$\mathrm{G}$ : Gini index

$\mathrm{Xi}$ : cummulative proportion of families at level $\mathrm{i}$

$\mathrm{Yi}$ : cummulative proportion of total incomes at level i

The decision criteria for evaluation of the disparity of incomes across farm households were set as follows :

$\mathrm{G}<0.4$ : Low level of disparity

$\mathrm{G}=0.4-0.5$ : Moderate level of disparity

$\mathrm{G}>0.5$ : High level of disparity

\section{RESULTS AND DISCUSSION}

\section{Characteristics of farmers}

The demographic characteristics of the farmers determined in the study covered farmer's age, gender, years of education, kinds of occupations, and income per year. These demographic characteristics of the individual farmers were compiled as potential indicators of the social and economy conditions of the the Labuhan Badas forest farming communities (Triyanto 2009; Subagio and Manoppo 2012).

\section{Age characteristics}

According to the Agency for Indonesia's Statistics Center, persons between the ages of 15 and 64 years are classified as economically productive. Therefore it could be assumed that the farmers maximally involved in the active work of the farmland both inside the community based forest $(\mathrm{HKm})$ as well as outside (the POF) were predominantly in this productive age group. Table 1 summarizes the distribution of ages among the farmers in the two groups.

In the productive age group (15-64 years), farmers can be regarded as capable of maximal farming efforts (Triyanto 2009). However, working persons of youthful age tend to migrate out of their village looking for jobs other than in the forestry sector. On the other hand, persons of ages 35 years and older tend to become more settled and absorbed in their daily work routines (Omobolanle 2007), associated with the fact the older the age the greater is a person's living expenses (Subagio and Manoppo (2012). 
Thus, it is this age group, those over 35 years of age, who represent the core work force in the forestry sector and many remain in this sector until leaving it in their old age (Wang et al. 2017).

\section{Years of education}

Levels of formal education for the HKm farmers varied from uneducated through to university graduate status; the average duration of their formal education was four years. Education level for the POF farmers ranged from uneducated through to second-diploma (D2) graduate status, with an average duration of formal education of five years. The characteristics of formal and non-formal education in the two groups of farmers are summarized in Table 2.

Many of the HKm farmers did not go to school, mainly because their homes were far away from the location of the nearest school. This situation contrasted with the circumstances of the POF farmers, whose easier access to schools enabled them to achieve higher levels of formal education than the HKm farmers.

\section{Types of occupation}

Details of income-earning occupations and of household roles of Labuhan Badas farmers are summarized in Table 3. If farmers own only small areas of farmland they are able to complete their farm work rapidly, and this means they have extra time to work off-farm to increase their incomes (Meert et al. 2005). The HKm farmers' circumstances have led many of them to pursue additional income fetching construction stone and sand (Table 3). On the other hand, the POF farmers were found to be more focused on farmland endeavors, mainly on crop-cultivation and on raising cattle. Off-farm employment limits the time that can be devoted to the main work in the agriculture fields (Su et al. 2016).

\section{Schedule of daily economic activities}

Determining an approximate schedule of daily economic activities is important to understanding how activities involved in farmers' income endeavours are able to be integrated along with other (e.g. domestic) activities in the daily round. The daily economic activities performed by females of both the HKm group and the POF group could be divided into two sectors, public activities and domestic activities. The domestic sector activities referred to routine work of the household such as cooking, cleaning house and taking care of children. The public domain referred to the attempt at earning income from activities such as cultivation of crops in the farm fields, rearing cattle, and fetching river stones. The detailed activities performed by farmers in the two groups are presented in Figure 2 and Figure 3.

The daily activities performed by the HKm farmers differed between the dry season and the rainy season. This was due to differences in the income sources between the two seasons. During the dry season, both male and female farmers used their time mostly to fetch stone and sand from the river, while during the rainy season they spent more time working in their farm fields.

Table 1. Age characteristics of the HKm and POF farmers of Labuhan Badas, Sumbawa, West Nusa Tenggara, Indonesia

\begin{tabular}{llllll}
\hline Gender & $\begin{array}{c}\text { Ages } \\
\text { (years) }\end{array}$ & $\begin{array}{c}\text { HKm } \\
\text { (persons) }\end{array}$ & $\begin{array}{c}\text { Percentage } \\
\text { of Hkm } \\
(\%)\end{array}$ & $\begin{array}{c}\text { POF } \\
\text { (persons) }\end{array}$ & $\begin{array}{c}\text { Percentage } \\
\text { of POF } \\
(\%)\end{array}$ \\
\hline \multirow{2}{*}{ Male } & $\leq 15$ & 0 & 0.00 & 0 & 0 \\
& 16 until 64 & 14 & 41.18 & 15 & 44.12 \\
& $\geq 65$ & 0 & 0.00 & 3 & 8.82 \\
& $\begin{array}{l}\text { Total } \\
\text { Female }\end{array}$ & 14 & & 18 & \\
& $\leq 15$ & 0 & 0.00 & 0 & 0.00 \\
& 16 until 64 & 20 & 58.82 & 15 & 44.12 \\
& $\geq 65$ & 0 & 0.00 & 1 & 2.94 \\
& Total & 20 & & 16 & \\
& & & & & \\
\hline
\end{tabular}

Table 2. Education characteristics of the HKm and POF farmers of Labuhan Badas, Sumbawa, West Nusa Tenggara, Indonesia

\begin{tabular}{lcccc}
\hline \multicolumn{1}{c}{ Education level } & HKm (persons) & $\begin{array}{c}\text { Percentage of } \\
\text { HKm (\%) }\end{array}$ & $\begin{array}{c}\text { POF } \\
\text { ( persons) }\end{array}$ & $\begin{array}{c}\text { Percentage of } \\
\text { POF (\%) }\end{array}$ \\
\hline Formal education & & & & \\
Uneducated status & 11 & 32.35 & 5 & 14.71 \\
Unfinished elementary school & 10 & 29.41 & 12 & 26.47 \\
Finished elementary school & 10 & 29.41 & 6 & 35.29 \\
Finished intermediate school & 1 & 2.94 & 1 & 17.65 \\
Finished high school & 1 & 2.94 & 1 & 2.94 \\
Second diploma Certificate (D2) & 0 & 2.94 & 0 & 2.94 \\
University graduate / S1-stratum & 1 & 100.00 & 34 & 0.00 \\
Total & 34 & & 1 & 100.00 \\
Non-formal education & & & 33 & \\
Seedling/cultivation skill & 6 & 17.65 & 34 & 2.94 \\
no skill & 24 & 100.00 & & 100.00 \\
Total & 34 & & & \\
\hline
\end{tabular}




\begin{tabular}{lccccc}
\hline Dry Season & a & B & C & D & e \\
\hline \multirow{2}{*}{ Times } & $4.30 \cdots->$ & $8.00 \cdots->$ & $13.00 \ldots->$ & $17.00 \ldots->$ & $22.00 \ldots \ldots-\ldots$ \\
\cline { 2 - 6 } & Morning & Noon & Afternoon & Evening & Night \\
\hline Rainy Season & a & b & C & D & e \\
\hline
\end{tabular}

Figure 2. The daily activities of the farmers of the privately owned forest (POF) during the dry and the rainy seasons Note:

\begin{tabular}{lll}
\hline \multicolumn{2}{l}{ Females } & Males \\
\hline A $\quad \begin{array}{l}\text { Morning prayer; cleaning houses and cooking; providing } \\
\text { fodder to cattle; preparing children for going to school; } \\
\text { preparing food packs for going to work in the gardens; }\end{array}$ & $\begin{array}{l}\text { Morning prayer (moslem); preparation for going to garden } \\
\text { (picking cashew fruits) }\end{array}$ \\
preparing for going to market & $\begin{array}{l}\text { Looking for work outside houses; hammering stones near } \\
\text { their houses; working in the gardens (cleaning the land; }\end{array}$ & $\begin{array}{l}\text { Performing activities in the gardens; eating breakfast; cultivation } \\
\text { in the gardens; picking cashew fruits; burning grasses; repairing }\end{array}$ \\
& $\begin{array}{l}\text { harvesting/picking cashew fruits; looking for teakwood and } \\
\text { mahoni seeds); taking rest in the gardens }\end{array}$ & fences; looking for firewood \\
C $\quad \begin{array}{l}\text { Taking a rest; prayer (moslems); preparing incense } \\
\text { (Hindu); going to the Hindu temples; taking care of houses }\end{array}$ & Taking rest; prayer \\
D $\quad$ Taking care of children (for praying, teaching) & $\begin{array}{l}\text { More working in the gardens; making preparation for returning } \\
\text { home; preparation for prayer (moslem) and Hindu prayer }\end{array}$ \\
E & Taking rest; watching TV; dinner; sleeping & Teaching children; prayer; taking rest; dinner; sleeping
\end{tabular}

\begin{tabular}{|c|c|c|c|c|c|c|}
\hline Dry Season & $f$ & g & I & g & J & k \\
\hline \multirow[t]{2}{*}{ Times } & $5.00-\cdots$ & $8.00-->>$ & $12.00-\cdots$ & $14.00-->>$ & $17.00-\cdots$ & 20.00 \\
\hline & Morning & Noon & Afternoon & Sunset & Evening & Night \\
\hline Rainy Season & $f$ & $\mathbf{h}$ & $\mathbf{H}$ & $\mathbf{h}$ & J & k \\
\hline
\end{tabular}

Figure 3. The daily activities of the community-base forest $(\mathrm{HKm})$ farmers during the dry and the rainy seasons Note:

\begin{tabular}{|c|c|c|}
\hline & Females & Males \\
\hline f & $\begin{array}{l}\text { Morning prayer; cleaning houses and cooking; preparing and } \\
\text { providing cattle fodder }\end{array}$ & Morning prayer; seeking and providing cattle fodder \\
\hline $\mathrm{g}$ & $\begin{array}{l}\text { Activities of looking for work outside houses; looking for } \\
\text { stones/pebbles at the river }\end{array}$ & $\begin{array}{l}\text { Looking for work at the river; collecting stones/pebbles, } \\
\text { and taking/procuring sand }\end{array}$ \\
\hline h & $\begin{array}{l}\text { Looking for work outside the household; going to cultivate the } \\
\text { fields, planting rice and other crops; looking for teakwood and } \\
\text { mahoni seeds; taking rest (break); if there was a lot of cultivation } \\
\text { work in the fields, then they remained there for a week }\end{array}$ & $\begin{array}{l}\text { Going to cultivate the fields (planting rice, sesame } \\
\text { seeds, soybeans, green peas, and pigeon peas) }\end{array}$ \\
\hline $\mathrm{i}$ & Taking rest (break); noon pray; tidying and taking care of houses & Taking rest (break); prayer \\
\hline $\mathrm{j}$ & $\begin{array}{l}\text { Taking rest (break); being socialized with neighbors; } \\
\text { worshiping/praying; cooking for dinner; watching TV }\end{array}$ & $\begin{array}{l}\text { Taking rest (break); worship/prayer; teaching prayer to } \\
\text { children; watching TV; dinner }\end{array}$ \\
\hline $\mathrm{K}$ & Taking rest (break); watching TV; sleeping & Taking rest (break); watching TV; sleeping \\
\hline
\end{tabular}


Table 3. Type of work conducted by the HKm and POF farmers of Labuhan Badas, Sumbawa, West Nusa Tenggara, Indonesia

\begin{tabular}{ccc}
\hline Type of work/ occupation & HKm & POF \\
& $\begin{array}{c}\text { Farmer } \\
\text { (persons) }\end{array}$ & Farmer \\
(persons)
\end{tabular}

Main work

- Farmer

- Household mother

- Sewer

- Stone and sand searchers

- Driver of truck for carrying stones and sand

- Teacher

Total

$\begin{array}{cc}19 & 31 \\ 1 & 1 \\ 0 & 1 \\ 12 & 1 \\ 1 & 0 \\ 1 & 0 \\ 34 & 34\end{array}$

Secondary work

- Farmer

- Household mother

- Cattle raiser

- Stone and sand searchers

- Carpenter

- Coconut tree climbers

- Retired employees

- Building laborer

Fried-crisp seller

Total

The income structure of the $\mathrm{HKm}$ and POF farm households are summarized in Figure 4. The income for each farm household was divided into two categories: the first category (on-farm) comprised incomes earned through activities associated predominantly with subsistence, performed in agricultural fields such as crop cultivation, cattle-rearing and selling, and farm labor; the second category pertained to incomes earned from non-agricultural endeavors (off-farm) which included salaries from labor other than farm labor, earnings from trading, earnings from industry, government employee's salaries, remittances for services rendered, and rewards for assistance given - as classified by Septiasari et al. (2013) and Saraswati and Dharmawan (2014).

\section{The total incomes}

Incomes for all farmers revealed similarity in the variety of sources drawn upon. Consequently, their incomes might have been expected to be almost equal in quantity. However, the factor that resulted in differences between farm household incomes was that there were differences between them in the time spent on the economic activities, in the number of family members involved in the economic activities, and in the ownership of the production factors.

On-farm agriculture was the dominant sector in the income structure of the POF farmers, while off-farm economic activity was the dominant sector in the incomes of the HKm farmers. Nevertheless, total incomes of the POF farmers were greater than those earned by the HKm farmers. Accordingly, the total incomes between those two farmer groups were revealed to be significantly different by t-test statistical analysis (Table 4).

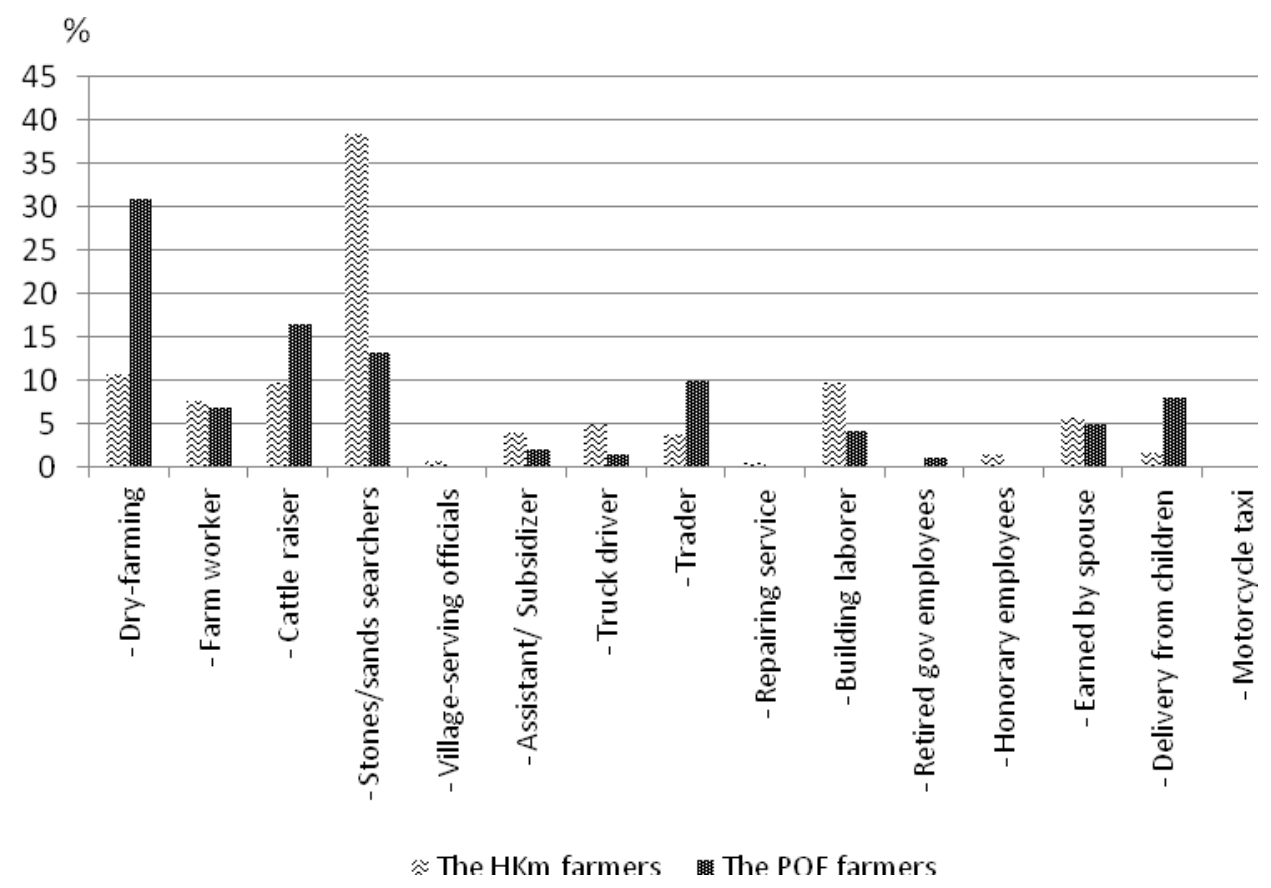

Figure 4. Structure of incomes earned by households of the HKm and the POF farmers of Labuhan Badas, Sumbawa, West Nusa Tenggara, Indonesia 
Table 4. T-test analysis of the difference in mean household income between HKm farmers and the POF farmers of Labuhan Badas, Sumbawa, West Nusa Tenggara, Indonesia

\begin{tabular}{|c|c|c|c|c|c|c|c|c|}
\hline & & \multirow{2}{*}{\multicolumn{2}{|c|}{$\begin{array}{l}\text { Levene's test } \\
\text { for equality of } \\
\text { variances }\end{array}$}} & \multicolumn{5}{|c|}{ t-test for equality of means } \\
\hline & & & & \multirow[t]{2}{*}{$\mathbf{t}$} & \multirow[t]{2}{*}{ df } & \multirow[t]{2}{*}{$\begin{array}{l}\text { Sig. (2- } \\
\text { tailed) }\end{array}$} & $\begin{array}{c}\text { Mean } \\
\text { difference }\end{array}$ & \multirow{2}{*}{$\begin{array}{l}95 \% \text { confidence interval } \\
\text { of the difference } \\
\text { Lower limit Upper limit }\end{array}$} \\
\hline & & $\mathbf{F}$ & Sig. & & & & & \\
\hline \multirow[t]{2}{*}{ Total incomes } & Equal variances assumed & 0.79 & 0.37 & 3.74 & 66.00 & 0.00 & 8791014.702346140 .65 & $4106793.74 \quad 13475235.66$ \\
\hline & Equal variances not assumed & & & 3.74 & 62.76 & 0.00 & 8791014.702346140 .65 & $4102286.13 \quad 13479743.27$ \\
\hline
\end{tabular}

Table 5. Income inequality (as indicated by Gini Indices) among the community-based forest $(\mathrm{HKm})$ farmers; the farmers of privately owned forest (POF); and the combined $\mathrm{HKm}$ and POF farmers of Labuhan Badas Village, Sumbawa, West Nusa Tenggara, Indonesia

\begin{tabular}{lc}
\hline Farmer unit & G-index \\
\hline The HKm farmers & 0.40 \\
The POF farmers & 0.25 \\
Combined category farmers & 0.32 \\
\hline
\end{tabular}

\section{Income distribution}

Table 5 lists the Gini Indices for the range of incomes among farmers. For Labuhan Badas Village as a whole, the low Gini Index value (of 0.32) indicated that there was no income disparity among farm households considered individually. However, within the HKm farmer group considered in isolation, the higher Gini Index value (of 0.40) suggested that there was a significant though moderate disparity in incomes among these communitybased forest farmers. The interview data revealed that not all of the HKm farm households were able to raise cattle nor to obtain additional income from sources outside of the forest sector. Such farm households had lower incomes than those of households who were able to more effectively diversify their income sources.

The situation was quite different for the POF farmers, who had similar opportunies to raise cattle. Besides, they also had similar involvements in processing cashew nuts into higher value products.

\section{Discussion \\ Characteristics of farmers}

It was found in this study that non-formal skills such as the cultivation of seedlings of teak (Tectona grandis) and mahogany (Swietenia macrophylla) was very rare among farmers in both groups. Nevertheless, it was found that $\mathrm{HKm}$ farmers had more time available to join training programs than did the POF farmers. This implies that farmers of the $\mathrm{HKm}$ group could hopefully gain from any training programs aimed at enhancing farmer's productivity as recommended by Perugini and Pompei (2017).

The HKm farmers could be incorporated in any land rehabilitation activities in Labuhan Badas Village, and in training programmes to enhance the farmer awareness of the benefits of maintaining the natural qualities of their environment and to encourage conservation of their forests (Mancini and Bruggen 2008). According to Sumane et al.
(2017), non-formal as well as formal education are jointly required to stimulate innovation in technology.

The education level of farmers has a significant effect on the allocation of time and effort to various economic activities. Education level also is a factor in farm householders' abilities to gain information and learn of opportunities to benefit from new economic endeavors. The low education level of the HKm farmers has apparently limited their ability to obtain job opportunities other than cultivation in the forest area. The HKm farmers seemingly have ambition far beyond their cultivation activityin the state forest area. Allegedly, by occupying the land inside the forest area for a long time, they hope some day to receive land certification from the government through land reform programs. This could be the main reason why they have earnestly defended the focus of their daily activities within the forest area, even though this has resulted in their incomes remaining at just subsistence level.

The cash incomes of the HKm farmers were dominated by non-agricultural sources, mainly by searching for stones and sand sold for construction. This was because they required financial capital for household living-necessities that could not be provided by their subsitence activities alone.

\section{The HKm farmers}

Saraswati and Dharmawan (2014) have categorised the assets of community forest farmers in the following terms: (i) human capital; (ii) physical capital; (iii) natural capital; (iv) social capital; and (v) financial capital.

Human capital refers to the number of persons in the community who are categorized as of productive age: all of the HKm farmers sampled in this study fell within the productive age group, 16-64 years. In our study the average duration of education background among $\mathrm{HKm}$ farmers was only 4 years. Only six of the farmers had followed skill training associated with cultivating seedlings of forestry plants

Physical capital refers to such things as vehicles that can be used in performing daily activities like going back and forth to schools, markets and farmland. In the research location there were no public transportation facilities, while the farmers' places of residence were quite far from public facilities. Most farmers (21 persons) obtained their vehicles through the credit system, while 11 persons obtained vehicles by cash payment, and two vehicles were purchased by the children of farmers. Other physical capital items such as farm land and buildings were not 
available, thereby resulting in low production and incomes from the agriculture sector. Similarly, cattle were in general owned by other people notthe HKm farmers themselves.

Natural capital refers mostly to the vegetation obtained from the local environment, either renewable or unrenewable resources. Unfortunately, the farmers owned no forest land themselves, as all their agricultural activities were conducted on state-owned lands. Diniyati and Achmad (2016) reported that not all of the plants in the forest area were available for use by the HKm farmers; some woody plant species were not allowed to be utilized.

$\mathrm{HKm}$ farmers had negligible individual financial capital. Their social capital was important, but only rarely did the farmers engage in organizational activities such as occasional gatherings associated with partial money saving (arisan), prayer undertakings, and farmer group activities. However, the relations among the community was very relaxed and friendly, as shown in particular social events such as religious rituals, marriage parties, funerals, etc. Accordingly, on such occasions, family members would participate cooperatively and assist each other in organizing social activities.

\section{The POF farmers}

In terms of human capital, $88.24 \%$ of the POF farmes sampled in this study fell within the productive age group, $16-64$ years of age. Their education in the main was equivalent to unfinished elementary school. Their work in the farmlands was often assisted by other family members.

The higher incomes earned by POF farmers was influenced by their form of private land ownership. Their ownership of the land was certified giving them legal title to the land as property. On average their area of land amounted to about 0.0191 ha. Similarly, the farmers owned livestock such as cows, pigs, and chickens. These animals served as a liquid capital asset, which would be utilized if they experienced sudden and urgent financial needs.

The farmers all owned vehicles; altogether, 12 bicycles and 35 motorcycles. There were five farmers who owned both motorcycles and bicycles. Moreover, there were seven farmer families who each owned more than one motorcycle. Having a vehicle was an essential asset allowing farmers to routinely perform their economic and other activities.

All farmers had natural assets of seasonal crops and woody plants.

The POF farmers were only rarely involved in social organizations such as periodic meetings associated with partial money saving (arisan), and with integrated services associated with human health (posyandu), etc. The main reasons for their relative independence from such social activities were that their finances were just sufficient for daily needs and their children were already grown-up. The owners of household shops trusted that POF farmers who purchased items from the shops would later pay for these goods when money was available.

There were 27 POF farmers in the survey who had access to credit, while 7 farmers were unwilling to access such credit, as they felt afraid they would be unable to pay it back. The process of accessing credit was very easy. POF farmers could receive favourable access to credit from the conventional bank (e.g., BRI) because their certified ownership of land could serve as a guarantee for the loan. Thirteen farmers reported having financial savings: seven had savings in the BRI bank; two had money held in a safe; and four persons had savings in the form of gold metal. This number was far greater than the number of $\mathrm{HKm}$ farmers with savings. Nevertheless, there was a total of 21 POF farmers who reported having no savings.

The financial capability of farmers was not high and most of them had only low capability to save money for their futures. Placing money in safes was quite common among the farmers, but placing savings in cooperative agencies and purchasing gold ornaments were occasional activities

Unlike the HKm farmers, the POF farmers had already established regular contact with the banks as part of their financial arrangements. This was because their incomes were more certain and because their land certificates could be used as financial security in their dealings with the bank. This situation was quite different from the HKm farmers who had no regular financial dealings with the bank business. This was attributable to the fact that they did not have certainty of income nor did they have any land certification to use as a bargaining chip.

More POF farmers than HKm farmers were in receipt of external financial remittances. Eight POF farmers $(25.53 \%)$ in the survey reported receiving remittances from their children working outside the village.

\section{Daily economic activities}

Farming in Indonesia is often thought of as the realm of men. But, in fact, in our study in Labuhan Badas Village farming activities were generally performed by both men and women. Females were actively involved in nondomestic income earning activities in the public domain. Female apart from their work as household mothers also assisted in improving household welfare by allocating part of their worktime to cultivating the household's fields and if possible to other informal income-earning activities (Arsal 2015). The percentage of females involved in activities in the public domain was $58.82 \%$ in the $\mathrm{HKm}$ forest area and $44.12 \%$ in the POF forest area. The higher percentage of females in the HKm area involved in public domain activities outside the domestic hearth was due to the perception amongst $\mathrm{HKm}$ households that the task of educating children in the home was a man's responsibility. This perception was in part due to their low overall education level.

\section{Male farmers}

The daily economic activities conducted by male $\mathrm{HKm}$ farmers were basically similar to those of male POF farmers. The activities were divided into two groups i.e. activities in the rainy season and activities in the dry season. The kinds of work performed in dry and rainy season differed from each other.

In the dry season, economic activities performed by male $\mathrm{HKm}$ farmers were predominantly those of collecting stones and sand; and working as truck drivers. On the other 
hand, in the rainy season, more of HKm men worked in the farmfields.

The daily economic activities performed by the male $\mathrm{HKm}$ and the POF farmers in general were similar. Their daily economic activities in the public domain was greater in number of hours and intensity than their work in domestic duties; they devoted about 7 hours per day (in dry season) and about 9 hour per day (in rainy season) to their activities in the public domain outside the house. During the planting season, farmers stayed in the cultivation fields for 3 months to perform land processing and planting work. Other work carried out by males were activities in cattleraising and in looking for stones and sand at the river.

\section{The female farmers}

There was a strong suggestion that female Hkm farmers were quite motivated on a daily basis by opportuinties to earn cash uincome. Their daily activities devoted to public work outside the house amounted to 6 hours on average, while the rest of their day was spent on domestic duties.

The women in Labuhan Badas Village exhibited significant productive roles, such that the incomes they earned greatly supported the economy of their families. As asserted by Warsito et al. (2011), the roles of women in poor families are multi-faceted including (1) seeking incomes for living necessities, either in a supplementary role or as the primary income-seeker; (2) performing duties as family mothers (productive in domestic work, not directly earning incomes, but supporting other family members to earn the finances for living-necessities); and (3) contributing as community members.

There were similarities between the female HKm and the female POF farmers in their activities in the public domain; in both groups there were more women than men involved in activities of collecting stones and sand. This is presumably because the location of the stone and sand resources was closer to their houses, enabling their work outside the house to be carried out once having finished their domestic work. In addition, this made it easy for women to return to their houses, when they were through with looking for stones and sand at the river.

\section{The structure of household incomes}

The farmers' incomes were dominated by earnings from activities associated with natural resources available near their living places. However, most farmers realised that if they had relied on just incomes earned from the agricultural sector, they would not have sufficient finances to meet the living needs of their households. Thus, they implemented a strategy of so-called 'multiple, diversified livelihoods' (Saraswati and Dharmawan 2014). The farmers devoted a lot of efforts to the non-agricultural sector; and several farm households had grown-up offspring involved in cycles of out- migration to work as laborers and as shopkeepers in the town. Migration to the town was commom among children of the POF farmers, and represented a strategy that sustained the resilience of farmers in earning incomes from occupations outside the agricultural sector (Saraswati and Dharmawan 2014).
Figure 4 revealed that the HKm farmers were more varyied in their income-earning attempts, despite the fact that their incomes were relatively small in value. In contrast, although income sources of the POF farmers varied less, their total earned incomes were greater. Based on the t-test it was inferred that the total incomes earned by $\mathrm{HKm}$ farmers were smaller than those earned by the POF farmers; from the assembled income data it is inferred that the total annual incomes earned by the HKm farm household reached IDR 11,827,074 per year, which was smaller than the incomes of the POF farm household (IDR 20,618,088 per year).

The lower incomes for the HKm farmers were attributed to the fact that they did not have ownership over their resources; and moreover, that their ability to access these resources was low. While human capital and social capital were similar between HKm farmer and POF farmer, other assets to meet living-requirements - physical capital, natural capital and financial capital - owned by $\mathrm{HKm}$ farmers were far smaller than was the case for the POF farmers. The $\mathrm{HKm}$ farmers generally raised livestock belonging to other people, and shared the offspring of the livestock. In contrast, the POF farmers were sole owners of the livestock they raised. As a result, the incomes from this economic activity was much smaller for $\mathrm{HKm}$ farmers than for POF farmers.

The disparity in incomes was not observed only in the differences between the two farmer groups, but also to a moderate extent, between individual farm households within the HKm group. This was due to disparity in the number of their income-earning sources. Diversification of income sources outside of the forestry sector was a good strategy for farmers to increase their incomes, particularly when their farmlands were very limited (Kalavathi et al. 2010; Birthal et al. 2014; Zhao 2014). In relation to that, $\mathrm{HKm}$ farmers spent significant time collecting stone and sand, because this natural resource was abundant in their vicinity. The women farmers even entered into contract with buyers who required timely delivery of the stone and sand. Most of HKm farmers originally came from out side forest area (mainly from Lombok), but only some of them like to occasionally travelling to their home town to earn additional imcomes. Besides, only some of them were interested in raising livestocks of other people by sharing the offspring. Those two additional economic activities made some of them gained higher total incomes than others.

The diversity of jobs performed by HKm farmers was greater than for the POF farmers. The jobs of the HKm farmers, especially of the women, were not only distributed across several economic endeavours (i.e. as farmer, as a stone and sand collector, as catle raiser), but also include non-income earning domestik endeavors (i.e. as household mother). On the other hand, POF farmers tended to mostly consentrate on one main endeavour, namely agriculture. This difference between the two groups in the complexity of thier income-earning activities contributed to the the differences in the level on their total income.

This difference in complexity was also observed in the types and level of education of the two farmer groups: the 
HKm farmers had a more diverse educational attainment than the POF farmers. Education level also is recognised as having an impact on adoption of technologicalk innovation (Bucciarelli et al. 2010; Rooij 2011). Higher levels of education lead to more developed thinking patterns, which facilitate decision-making especiaaly in relation to uptake of new technologies (Subagio and Manoppo 2012). The education of $\mathrm{HKm}$ farmers ranged from from uneducated status to trough to university graduate status. This disparity in education had an impact on the farmers' access to economic endeavors and in turn was a factor in the moderate disparity in household incomes among the HKm community.

In conclusion, activities performed by all farmers comprised both agricultural and non-agricultural endeavors. The community-based forest $(\mathrm{HKm})$ farmers had 14 sources of income while the farmers of privately owned forest (POF) had 12. The principle non-domestic, income-earning activities of female farmers was in seeking for stones and sand at the river, while the main activities of male farmers were agriculture, in the farm fields. Nondomestic activities performed by $\mathrm{HKm}$ and POF female farmers in the public domain lasted for 6 hours and 5 hours per day, respectively. Economic activities performed outside the house by HKm and the POF male farmers was of 8 hours duration for both groups. By relating the characteristics of farmers to their daily economic activities, we were able to ascertain why the incomes of the HKm farmers were on average significantly smaller than the incomes of the POF farmers. To improve their incomes, the farmers in both research locations (but especially the HKm farmers) had attempted to implement a so-called multiple, diverse, livelihood strategy; whereby the main incomes earned by the HKm farmers were from the non-agricultural sector $(71.66 \%)$, mainly from fetching stone and sand $(38.55 \%)$; while the incomes of the POF farmers were dominated by agricultural sources (54.53\%). Unfortunately, the difference in incomes between the HKm and the POF farmers was mainly due to differences in land tenure and cattle ownership. Moreover, differences in ability and intensity to carry out new income-earning endeavors between farmers within the HKm community has led to moderately disparity between farm households within their community.

The HKm farmers allegedly have a hidden hope that in the long-run their responsible farming activity within the state production forest will lead to them being given land certification through land reform programs. Such legal titles to land the land could be used by Hkm farmers as guarantees in pursuing credit from the banks. The incomeearning endeavours of the farmers have so far had not achieved maximal benefits. Our study suggests that there is sufficient time available in the work schedules of female farmers to enable them to take on additional promising economic activities. To achieve this opportunities need to be created for training in such new enterprise as the raising of honey bees, and the processing of cashew fruit and jackfruit. Such training would facilitate farmers in further diversifying their economic endeavors, thereby enhancing farm household incomes.

\section{ACKNOWLEDGEMENTS}

The authors are grateful to the Institute for Research and Development on Agroforestry Technology, Ciamis, West Java, Indonesia for the financing of this research. The authors also wish to convey their deep high appreciation to: the Head and Staff of the Batulanteh's KPHP (Forestry Enterprising District), of Sumbawa Regency, who accompanied the authors in their field research; to the $\mathrm{HKm}$ farmers who resided inside the forest area administratively under Kanar Luk's RKPH (Resort of Forestry-Enterprising District); and to the POF farmers outside the forest area, who were all enthusiastic in their cooperation throughout the stages of the research activities. Further appreciation is extended to the forestry technicians for their valuable assistance in collecting the field data.

\section{REFERENCES}

Arsal T. 2015. The involvement of women in the production of emping melinjo (melinjo chips) to improve the economy of rural farmer household. Komunitas 7 (2): 243-250.

Birthal PS, Negi DS, Jha AK, Singh, D. 2014. Income Sources of Farm Households in India : Determinants, Distributional Consequences and Policy Implications. Agric Econ Econ Rev 27 (1): 37-48.

Bucciarelli E, Odoardi I, Muratore F. 2010. What role for education and training in technology adoption under an advanced socio-economic perspective ? Procedia - Soc Behav Sci 9: 573-578.

Kalavathi S, Krishnakumar VP, Thomas RJ, Thomas GV, George ML. 2010. Improving food and nutritional security of small and marginal coconut growers through diversification of crops and enterprises. J Agric Rural Dev Trop Sub Trop 111 (2): 101-109.

Mancini F, Bruggen AHC Van. 2008. Increasing the environmental and social sustainability of cotton farming through farmer education in Andhra Pradesh, India. Agric Syst 96: 16-25.

Meert H, Huylenbroeck GV, Vernimmen T, Bourgeois M, Hecke EV. 2005. Farm household survival strategies and diversification on marginal farms. J Rural Stud 21: 81-97.

Newton P, Miller DC, Augustine M, Byenkya A, Agrawal A. 2016. Who are forest-dependent people? A taxonomy to aid livelihood and land use decision-making in forested regions. Land Use Pol 57: 388-395.

Olsson P, Galaz. 2012. Social-ecological innovation and transformation. In: Nicholls A, Murdoch A (eds.). Social Innovation: Blurring Boundaries to Reconfigure Markets. Palgrave MacMillan, Basingstoke, UK.

Omobolanle OL. 2007. Socio-economic conditions of peasant farmers : the case of agricultural technologies' sustainability in southwest Nigeria. African J Agric Res 2 (9): 441-446.

Pandey MK, Dwivedi AB. 2016. Understanding Socioeconomic Conditions of Rural Households. J Rural Dev 35 (4): 599-619.

Perugini C, Pompei F. 2017. Temporary Jobs, Institutions, and Wage Inequality within Education Groups in Central-Eastern Europe. World Dev 92: 40-59.

Rasmussen LV, Watkins C, Agrawal A. 2017. Forest contributions to livelihoods in changing agriculture-forest landscapes. For Pol Econ J. DOI: $10.1016 /$ j.forpol.2017.04.010

Rooij SWV. 2011. Higher education sub-cultures and open source adoption. Comput Educat 57: 1171-1183.

Saraswati Y, Dharmawan A H 2014. The Livelihood Resilience of Forest Community Farmer Household in Giriwoyo, Wonogiri. Jurnal Sosiologi Pedesaan 2 (1): 63-75. [Indonesian]

Septiasari MI, Diarta IKS, Dewi RK. 2013. Comparison between Farmers Household Income in The Subak of Tourism and Non Tourism Area. E-Jurnal Agribisnis and Agrowisata 2 (4): 236-246. [Indonesian]

Su W, Eriksson T, Zhang L, Bai Y. 2016. China Economic Review Offfarm employment and time allocation in on-farm work in rural China from gender perspective. China Econ Rev 41: 34-45.

Subagio H, Manoppo CN. 2012. The relationship between characteristic of farmer with chili farming business as impact of FMA learning (a 
case study at Sunju village, Marawola sub district, Center Celebes province). National Seminar on Food Autonomy. Institute for Agriculture Technology Examination. Malang, East Java.

Sugiyono, 2013. Research Methods for Quantitative, Qualitative and R \& D. CV. Alfabeta, Bandung. [Indonesian]

Sumane S, Kunda I, Knickel K, Strauss A, Tisenkopfs T, et al. 2017. Local and farmers ' knowledge matters! How integrating informa and formal knowledge enhances sustainable and resilient agriculture. J Rural Stud. DOI:10.1016/j.jrurstud.2017.01.020.

Triyanto. 2009. Perception, motivation, attitude and behaviour of local community to the existence of forest (case in Gunung Kencana subdistrict, Lebak district, Banten Province. Bogor Agriculture University, Bogor. [Indonesian]

Wang W, Jin J, He R, Gong H. 2017. Science of the Total Environment Gender differences in pesticide use knowledge, risk awareness and practices in Chinese farmers. Sci Total Environ 591: 22-28.

Warsito W, Sumarwan U, Ananto EE, Sunarti E, Dharmawan AH. 2011. Livelihood Source of Poor Farmers in Teak Forests and Food Fulfillment (Case: Six Villages in Blora District). Penelitian Hutan Tanaman, 8 (2): 59-80. [Indonesian]

Zhao J. 2014. Rural income diversification pattern and their determinants in China. Agric Econ-Czech 60 (5): 2019-231. 